\title{
Connecting Māori Youth and Landscape Architecture Students through Participatory Design
}

\section{Maria Rodgers, B. Marques \& J. McIntosh}

To cite this article: Maria Rodgers, B. Marques \& J. McIntosh (2020): Connecting Māori Youth and Landscape Architecture Students through Participatory Design, Architecture and Culture, DOI: 10.1080/20507828.2020.1768349

To link to this article: https://doi.org/10.1080/20507828.2020.1768349

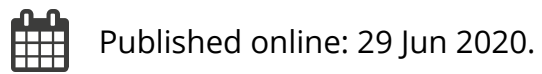

Submit your article to this journal 둔

Q View related articles ¿

View Crossmark data ¿ 


\section{ARCHITECTURE AND CULTURE}

Maria Rodgers

Victoria University of

Wellington - Te Herenga

Waka

Maria.Rodgers@vuw.ac.nz

B. Marques

Victoria University of

Wellington - Te Herenga

Waka

bruno.marques@vuw.ac.nz

\section{J. Mclntosh}

Victoria University of

Wellington - Te Herenga

Waka

jacqueline.mcintosh@

vuw.ac.nz

Keywords: community engagement, Indigenous youth, landscape

architecture, participatory

design, co-design

Check for updates

pp 1-19

DOI:10.1080/20507828.

2020.1768349

\section{No potential conflict of} interest was reported

by the author.

(c) 2020 Informa UK Limited, trading as Taylor \& Francis Group

\section{Connecting Māori Youth and Landscape Architecture Students through Participatory Design Maria Rodgers (1), B. Marques (1) and J. Mclntosh (1)}

ABSTRACT As with many Indigenous cultures, the Māori connection to the land in Aotearoa New Zealand has been weakened by colonization, urbanization and other factors. In particular, Māori youth in their progressively technological world, experience a disconnection from their culture and their land (whenua). Using a participatory design method and designing with the land is proposed as a way to enable cultural reconnection through the reconstruction of identity. Developing ideas from community engagement and place-making with Indigenous groups, in this research landscape architecture students joined with Māori youth (rangitahi) attending an alternative education program to co-design a public community space. The article reflects on the benefits of the community-based participatory research methodology for both groups, including the development of an understanding of the importance of Indigenous knowledge and rebuilding connection to culture and land.

\section{The Deep Connection of Māori to the Land}

For the Māori ${ }^{1}$ of Aotearoa New Zealand the land, the whenua, ${ }^{2}$ is a part of themselves and they are a part of the whenua. "Early European 
Connecting Māori Youth and Landscape Architecture Students through Participatory Design Maria Rodgers, B. Marques and J. Mclntosh settlers believed that land belonged to and was owned by people. This contrasted with the Māori view that people belonged to the land." 3 The strong connection between land and Indigenous people is well documented, as is the loss of that connection in the face of urbanization and colonization, resulting in ongoing challenges, social, economic and political. ${ }^{4}$ For rangitahi (or Māori youth) disconnection from the whenua is often combined with disconnection from culture and wider community. This article explores the ways in which a participatory landscape design project can address these issues. It explores the potential of collaborative engagement between Māori youth and university students co-designing a public open space as a means of reconnecting to the whenua and to community.

Māori had and continue to have a different relationship with landscape to the European, or Pākehā. ${ }^{5}$ For Māori, the whenua is a part of themselves and they are a part of the whenua. This is most clearly illustrated through the content of a mihi or mihimihi, ${ }^{6}$ during which:

A person will usually identify specific geographical features associated with their tribal area including their maunga (mountain), awa (river) and moana (sea) .... This information is considered more important than the individual's own name which may be the last piece of information given in mihimihi. ${ }^{7}$

Murton explains how being one with the land is expressed deeply in Te Reo Māori, ${ }^{8}$ in which "the word whenua means both 'earth' and 'placenta,' and as such metaphorically represents the connection of people to their origins, material, historical, and spiritual."9 Māori bury both the placenta and pito ${ }^{10}$ in the ground following the birth of a child. This symbolically inserts the newborn back into the land reflecting the connection between place and people and grounding an individual or group to a specific place. ${ }^{11}$

In Aotearoa New Zealand there is a desire by those who design with the landscape to emulate the deep connection of Māori to land. The preamble of the NZILA (New Zealand Institute of Landscape Architects) Aotearoa New Zealand Landscape Charter of 2010 acknowledges the importance of the fundamental relationship the tangata whenua ${ }^{12}$ have with the natural world. It goes on to state, that "where appropriate, those attitudes and beliefs should influence and inform the ways in which we approach the protection, planning, design and management of our landscapes."

\section{The Challenges for Indigenous Youth}

In this increasingly complex world, where technology, media and a variety of disembodying stimulants demand attention, Indigenous youth face additional challenges to non-Indigenous youth. Place disconnection, from the whenua, means that Māori are further disadvantaged. A report on 
Indigenous youth, that took a holistic view of wellbeing as spiritual,

emotional and physical wellness, found that spirituality was the aspect most damaged during European colonization and so it is this aspect of young people that needs special attention. ${ }^{14}$ In this vein, when designing programs to help young Indigenous people reach their full potential, cultural knowledge and practices must be incorporated for wellbeing to be sustainable. How Māori can be enabled to reconnect to the whenua and to their culture is a question posed repeatedly in Aotearoa, and ways of reconnecting youth to their whenua, their culture and to society, are widely sought.

\section{Using Co-Design and Participatory Design to Reconnect to the Land}

Nationally and internationally there are few examples of how community engagement and co-design involving Indigenous youth, landscape design and horticulture can come together to enable beneficial place-making. ${ }^{15}$ For racially or economically marginalized young people, integrating landscape architecture, environmental education and environmental justice can achieve good design, stewardship and activism. ${ }^{16}$ Research on community design involving children suggests that, "place-making has benefits for children, especially those who are alienated from their surroundings or from mainstream channels of achievement." 17 These benefits include developing empowerment, a sense of caring for the planet and its ecosystems, and an increased connection to other people and to nature. ${ }^{18}$ Others concur stating, "engaging children in experiential learning enhances their sense of community, place, and belonging, as well as enhancing their lives. They learn that they have something to contribute and that they have the opportunity to participate in making a qualitative difference in shaping the places where they live." 19 Transforming public space can become an empowering process. ${ }^{20}$

Participatory landscape design has the potential to build an ethic of care and landscape stewardship in the individual, with the potential for added social benefits for rangitahi. ${ }^{21}$ Fostering place-making activities provides stability and is integral to self-definition. ${ }^{22}$ Traditional usercentered design approaches have been criticized for viewing users as passive. ${ }^{23}$ Recent ideas from Northern Europe lean toward a participatory co-design approach with the user as partner and emphasis placed on input given throughout the design process. ${ }^{24}$ In a project involving high school youths who constructed their own outdoor classroom, the collaborative approach was seen to positively contribute to young people's sense of self and collective identity. ${ }^{25}$

Co-design can be defined as, "A practice where people collaborate or connect their knowledge, skills and resources in order to carry out a design task." ${ }^{26}$ Co-design is described as a process of collaborative thinking where diverse people actively participate in all aspects of the design. ${ }^{27}$ In this vein, the user, or co-designer is not necessarily from a design background, and can become part of the design 
Connecting Māori Youth and Landscape Architecture Students through Participatory Design Maria Rodgers, B. Marques and J. Mclntosh team if given appropriate tools to express themselves. ${ }^{28}$ The researcher or designer can pass on appropriate tools and act as facilitator rather than translator as in the traditional design process. In this pedagogical research project, diverse people were brought together to collaborate, the rangitahi were the users, and landscape architecture students translated the design process for them, enabling the design of a successful outdoor space.

Sanders discusses the change within design thinking from usercentred to participatory approaches and argues that this is not simply a matter of method, but a change in perspective where the discipline of design can be seen as a network rather than a hierarchy. ${ }^{29}$ Till considers that "true participation demands that the process is two-way," with the user's knowledge and experience potentially being transformative for the designer. ${ }^{30}$ Landscape architects in Aotearoa New Zealand who practice true participatory design with those Māori who have a deep connection to the land will experience the rich benefits of this two-way process.

Increasingly, tertiary institutions are including participatory design in their curriculums. ${ }^{31}$ Two Aotearoa New Zealand student projects concluded that, "The interdisciplinary collaborative research process can create new opportunities for architectural design education as it educates students and the wider community as active world-citizens." ${ }^{32}$ Similarly, a Texan project involving landscape architecture students with youth from a Juvenile Justice Alternative Education Program in the design of a nature trail describes the positive impact on the at-risk youth. "The introduction to nature and the outdoors helped them to open up and describe how they believed they could help and become productive citizens," ${ }^{33}$ concluding that:

In almost every aspect of a landscape architect's professional practice, the designs and projects they develop ultimately serve to enhance the surrounding community ... Consequently, students of landscape architecture, in conjunction with their environmental stewardship, need to develop civic responsibility, to better serve the public at large. ${ }^{34}$

\section{A Landscape Architecture Co-Design Project}

Seeking to apply these ideas in the Aotearoa-New Zealand context, this research project engaged with the small rural town of Carterton situated in the Wairarapa region of the lower North Island, one and a half hours drive from the capital city Wellington. The population of the Carterton district was 8,235 in 2013. ${ }^{35}$ The rangitahi were aged between 13 and 15 years of age and attending the Autaia Alternative Education Program (AAEP) situated in the grounds of St Mark's Anglican Church and led by Ngāti Kahungungu ki Wairarapa, one of the iwi ${ }^{36}$ who are mana whenua ${ }^{37}$ in Wairarapa. "Alternative Education" is a short-term intervention which 
supports students alienated from mainstream education and aims to reengage them in meaningful learning targeted to their needs, supporting them in their transition back to mainstream school, further education, training or employment. ${ }^{38}$

The curriculum of the AAEP aimed to help students learn more about Mātauranga Māori ${ }^{39}$ and the close relationship Māori have with the whenua. The program sought to enable the rangitahi to reconnect with their cultural roots, iwi and whenua, and to better understand the role of kaitiaki $i^{40}$ of the natural environment, one of the traditional principles embedded in Māori culture. The concept of kaitiakitanga ${ }^{41}$ is where "human, material and non-material elements are all kept in balance" - an aspiration that those running the program had for the rangitahi. ${ }^{42}$

The idea for the co-design project developed from the relationship established between Ngāti Kahungungu ki Wairarapa and the landscape architecture program at Victoria University of Wellington, Te Herenga Waka (VUW), where a series of student design projects sited in the Wairarapa were undertaken over a five-year period under the guidance of members of the local iwi. The collaborative project met objectives of fostering experiential learning and teaching; service learning and engagement; and compliance with the bicultural objectives of Aotearoa New Zealand. ${ }^{43}$ The AAEP saw the potential of collaboration between the students and the rangitahi to grow reconnection to the land and the environment, and the eleven Masters of landscape architecture students who volunteered to participate saw the project as a way to give back to the iwi who had been so welcoming and inspiring during their design projects. At the time, the landscape architecture students did not envisage the learning they would experience themselves as a result.

In VUW's landscape architecture program there is a commitment to creating opportunities for students to engage with tangata whenua. The aim is to enable the attitudes and beliefs of tangata whenua to inform the way students design, a principle advocated for all landscape architects by the NZILA charter. ${ }^{44}$ During the series of studios in partnership with Ngāti Kahungungu ki Wairarapa, students stayed at marae, ${ }^{45}$ were immersed in the kawa ${ }^{46}$ of the marae and heard some of the pūrākau. ${ }^{47}$ Each group's work was taken back to the local people, via exhibitions and presentations where the results of the students working with the Wairarapa landscape was received with much enthusiasm by both Māori and Pākehā who call it home.

The first meeting between the university students and the rangitahi took place at Papawai Marae, close to Carterton, where the rangitahi were experiencing noho marae, ${ }^{48}$ immersed in the tikanga ${ }^{49}$ and kawa of the marae (Figure 1). During the year the rangitahi visited all nine marae in Wairarapa where they had personal connections. They were reintroduced to the stories of the ancestors depicted in the wharenui, ${ }^{50}$ to their culture and to the wider community. The importance of the landscape to them as tangata whenua was stressed through pūrākau 
6

Connecting Māori Youth and Landscape Architecture Students through Participatory Design Maria Rodgers, B. Marques and J. Mclntosh

Figure 1

Top: Rawiri Smith telling iwi stories at Papawai Marae;

Bottom: Kohunui Marae,

South Wairarapa.

Photographs by Maria

Rodgers taken 12 August and 23 September 2015.
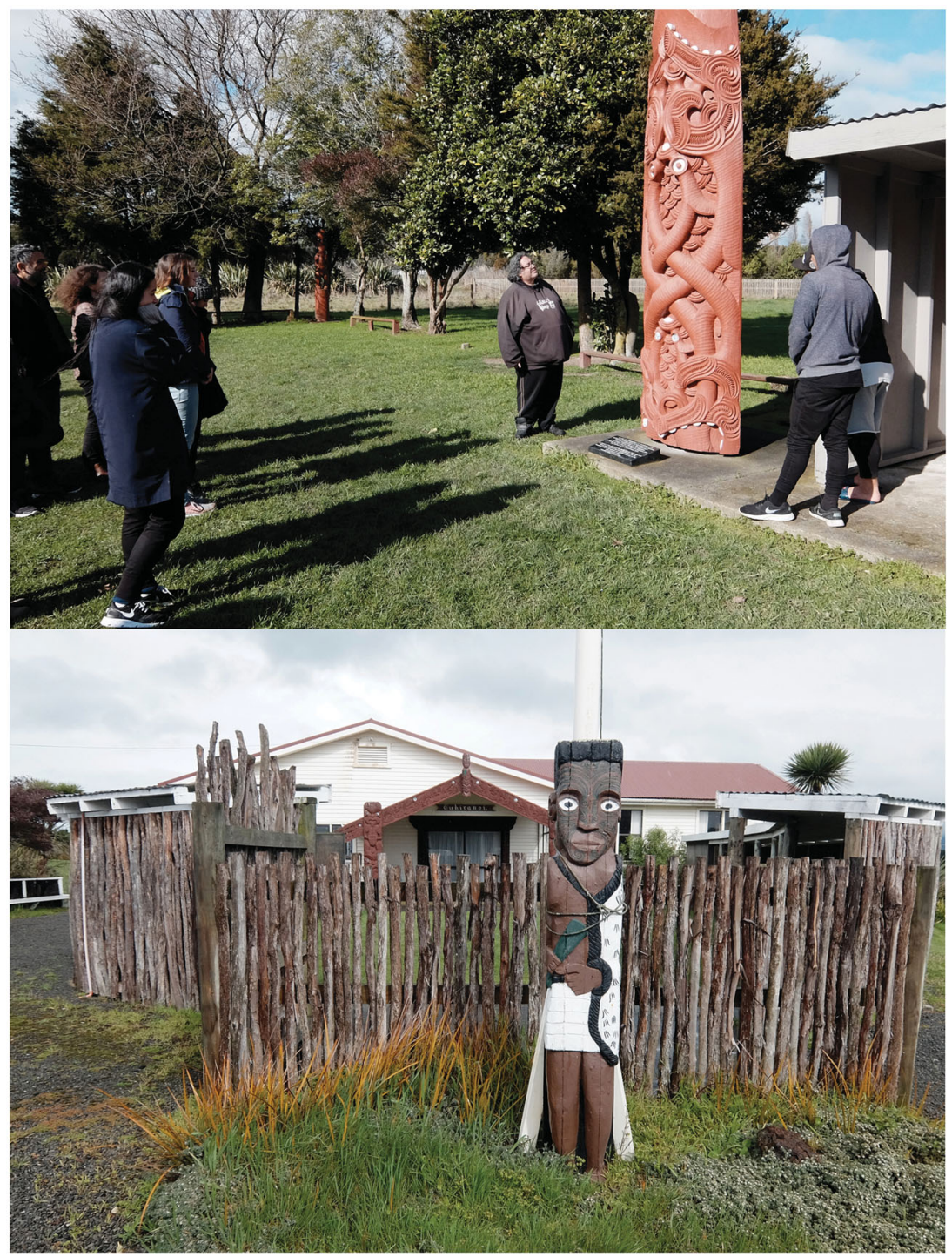

that interweave landscape and ancestors. They also experienced the communal life of the marae, helping with meal preparation, eating together and sleeping alongside one another in the wharenui.

The project commenced with a traditional pōwhiri ${ }^{51}$ at the Papawai Marae. This was followed with stories of the land, the ancestors and the striking carvings that surround the marae. The rangitahi also learned something of the kaupapa ${ }^{52}$ of landscape architecture and, as is traditional, kai ${ }^{53}$ was shared. The university students joined the rangitahi at a second noho marae, at Kohunui Marae, south of Carterton and the experiences of the interweaving of land and culture continued. 


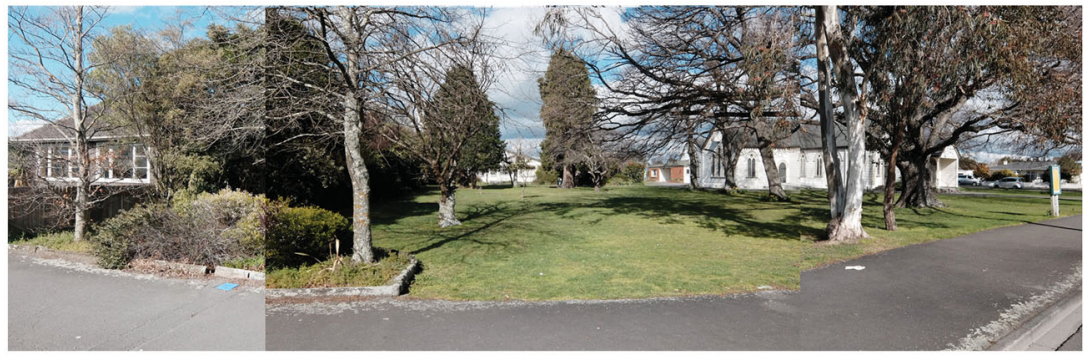

The project was planned to run for six weeks with twice weekly visits by the university students to the AAEP classroom. The site selected for intervention was located within the church grounds and was therefore common ground, shared between the rangitahi who used it, with their classroom in a church building, and the church community who endorsed the project. The site was also a highly visible part of the grounds but had become neglected, creating the opportunity for redesign which would have a positive impact on the parishioners and wider community (Figure 2).

A five-stage process was drawn up (Figure 3). A meeting was held with church leaders to establish the possible changes that could be made to the church property and a brief was developed to redesign the northern area of the site. The focus of each session was planned in discussions between the teacher and student leaders. The university students worked one-on-one with the rangitahi as the youth experienced for the first time designing their environment and designing with the land. Much discussion ensued regarding their ideas and suggestions for identifying the potential for development. The AAEP teacher included specific tasks so the rangitahi could achieve various NCEA (National Certificate of Educational Achievement) unit standards, such as mathematics, as part of the project.

The first step in the design process saw the university students seek to 'break the ice', sharing images they had gathered of design precedents, including examples of planting and hard landscaping. The rangitahi followed the students' lead and sought out images they liked and thought suitable as well. After this initial exercise, the students led the rangitahi in a traditional western survey, analysis, and design process. A simple survey was then undertaken by the rangitahi and one of the university students drew a scaled plan of the site. Using this plan as a base, the rangitahi sketched ideas for the project. The students worked with the rangitahi to encourage them to assess and develop their ideas, to learn which plants were suitable, and to develop plans, perspective drawings and physical models to communicate their designs. Having the AAEP teacher continue in her role enabled the landscape students to be mentors, rather than taking a leading role. 
Connecting Māori Youth and Landscape Architecture Students through Participatory Design Maria Rodgers, B. Marques and J. Mclntosh

\section{Figure 3}

Top left: Project planning; Top right: A rough plan of the site; Bottom: An area of the site that was overgrown. Photographs by Maria Rodgers taken 26 August 2015.

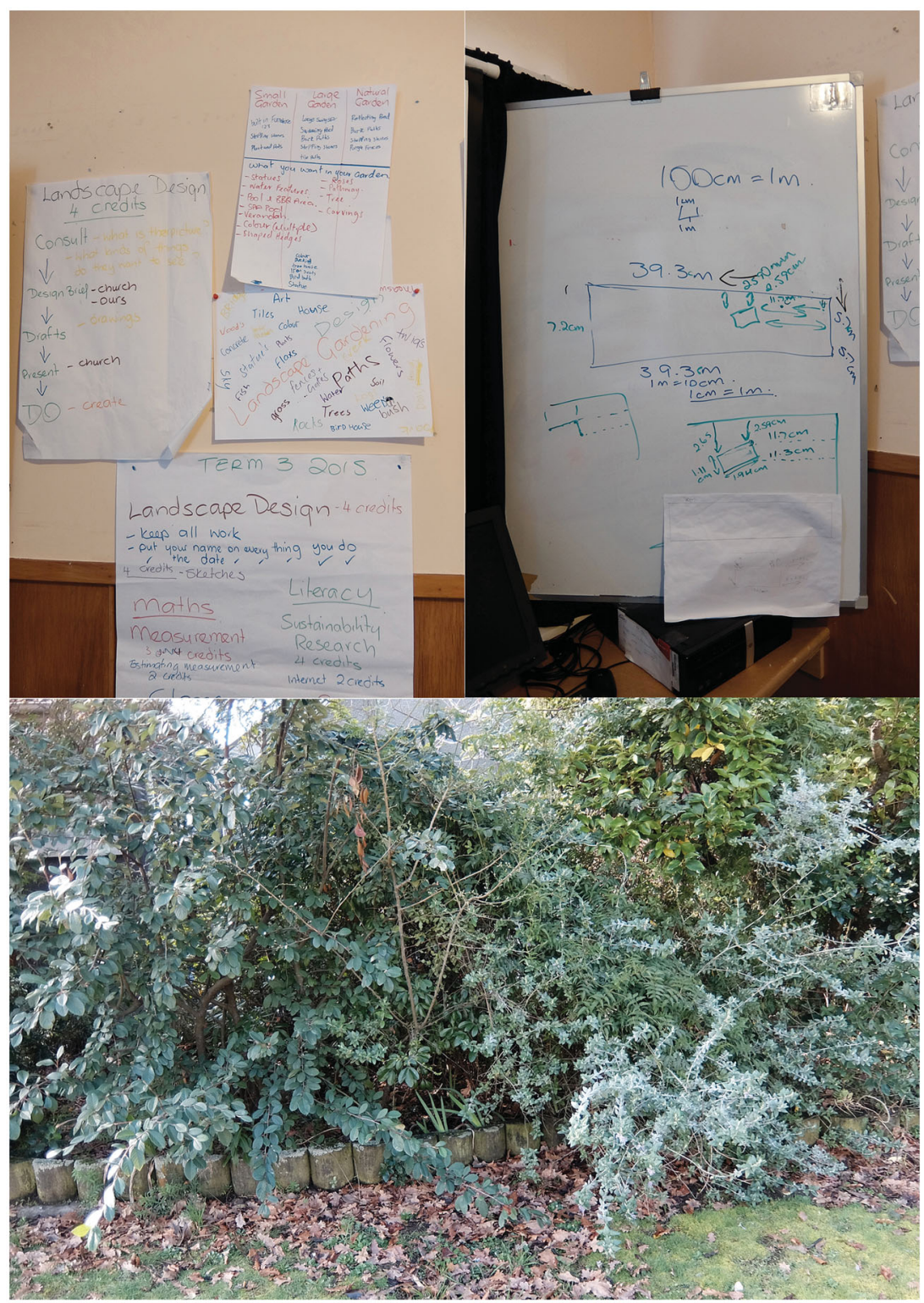

The task to bring together everyone's ideas into a single design required skilled management on the part of the teacher and the university students to ensure all ideas were accommodated. Once the proposed composite design was agreed on by the rangitahi, the university students helped to prepare them for the spoken and visual presentation of their design proposal to the church community. Feedback from the church community was positive and useful, and the design was adjusted accordingly. The rangitahi then developed the budget, calculating the amount of materials needed for each aspect, such as the stones for mulch, timber for signage and plants. 
The university student leaders worked with their peers to identify individual skills and how best to employ them. Members of the wider community were approached and asked to contribute either personal or financial assistance. Many agreed and made generous contributions: a local native nursery donated plants and a hardware store donated building materials and paint for the garden edging and fence. The generous support of the wider community was hugely empowering for the rangitahi and the work they were doing.

During the implementation stage, a tragic event occurred involving the death of one of the rangitahi. This had a significant impact on the entire group. Some of the university students attended the funeral. Grieving together increased the bond between the students and the rangitahi, but also affected the energy and enthusiasm for the project. As a result, work stopped for a period of time and the project was scaled down, reducing the size and number of structures included. The construction of proposed timber seating and shelters was deferred, but removal of unkempt vegetation and rampant weeds was undertaken, and remaining trees and shrubs pruned. The garden edging and old fence were repainted and additional stone edging installed. New plants were selected and planted, with consideration given to the site conditions they preferred, their habit and ultimate size. The planted areas were then mulched with local river stones and a seat was added to the footpath edge (Figure 4). A special birdbath was designed and installed as a memorial to the student who had died.

To showcase what the students had accomplished and to bless the space, an opening ceremony was organized with invitations sent to church members, to those who had contributed, to the families of the rangitahi and to the iwi (Figure 5). After karakia ${ }^{54}$ kai was shared and a ceremony held where all participants were acknowledged. The rangitahi each received patu, ${ }^{55}$ and the university students each received mau kaki. ${ }^{56}$ Those in attendance found the ceremony meaningful and moving (Figure 6).

\section{Reflecting on the Autaia Participatory Project}

To evaluate the project, a questionnaire was distributed to the university students seeking feedback on the process and the outcomes for both themselves and the rangitahi. The AAEP elected not to survey the rangitahi directly. The university students considered that the most positive impacts on the rangitahi were the hands-on creativity that the project fostered and how participating led to pride in the finished outcome. University Student A said, "the practical 'hands-on' experience rewarded with a physical outcome ... instilled a sense of achievement and pride." Student B felt the rangitahi were "more responsive and engaged when it came to doing more hands-on activities." Student C considered many of the rangitahi "were very artistically talented which showed after they felt more relaxed and excited about the project and 
Connecting Māori Youth and Landscape Architecture Students through Participatory Design Maria Rodgers, B. Marques and J. Mclntosh

\section{Figure 4}

Installing the seat - the teacher, Emma Cameron, and university students are on the left and in the middle, with two of the rangitahi on the right. Photograph by Maria Rodgers taken 24 November 2015.

\section{Figure 5}

The blessing of the garden with representatives of the church community and AAEP. Photograph by Maria Rodgers taken 8 December 2015.
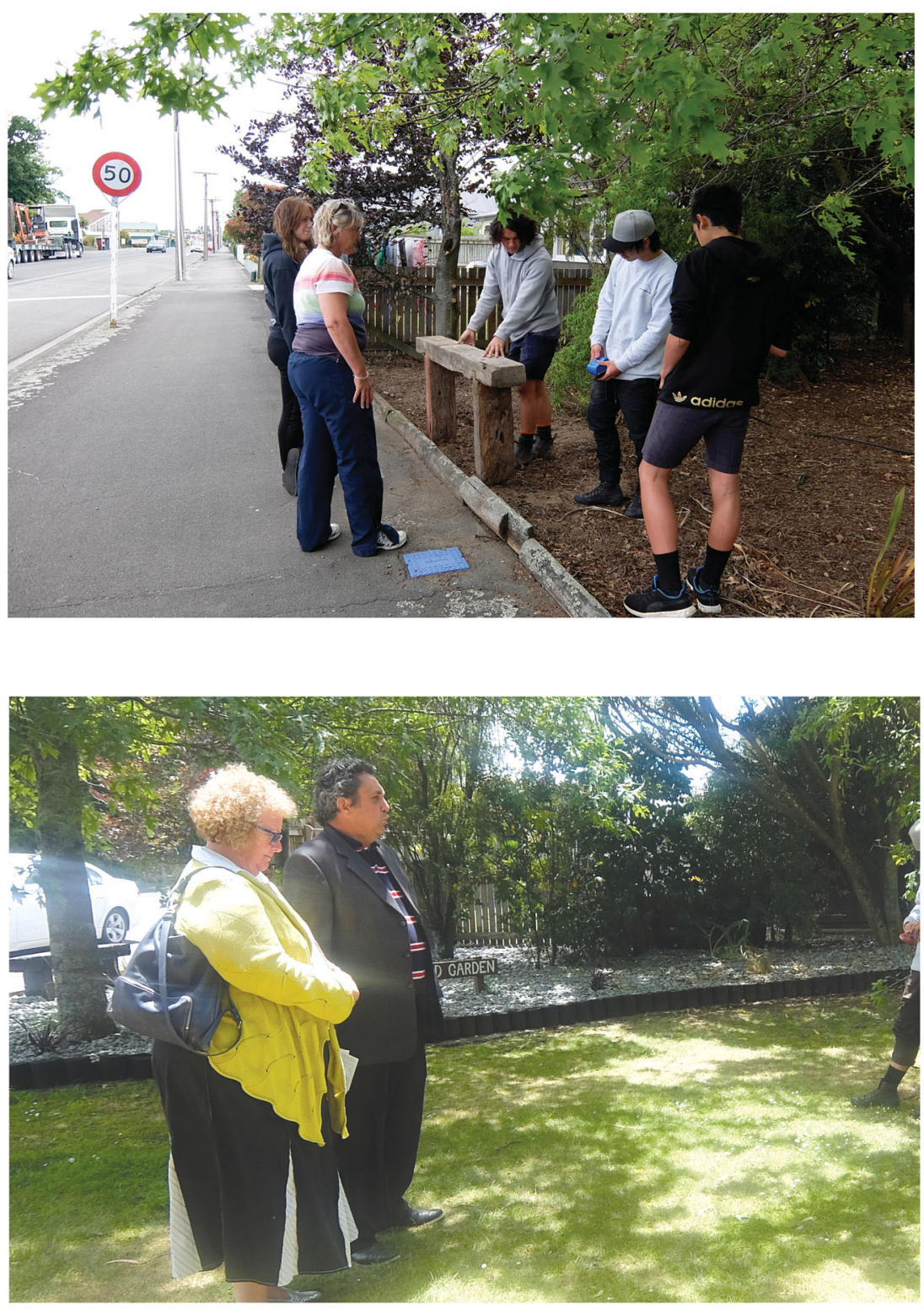

were freer in showing their abilities." As the project went on, relationships grew and a team culture developed. For Student A, "being able to witness the progression of their efforts led them to encourage each other." For Student B another positive "was the support they were giving one another with the outdoor physical activities when they proved difficult." Student D considered "they were no longer just solely focused on themselves."

The university students found their efforts were well rewarded by the project. Student A said that "having potentially sparked a new interest in some students [rangitahi] was definitely a personal highlight." 


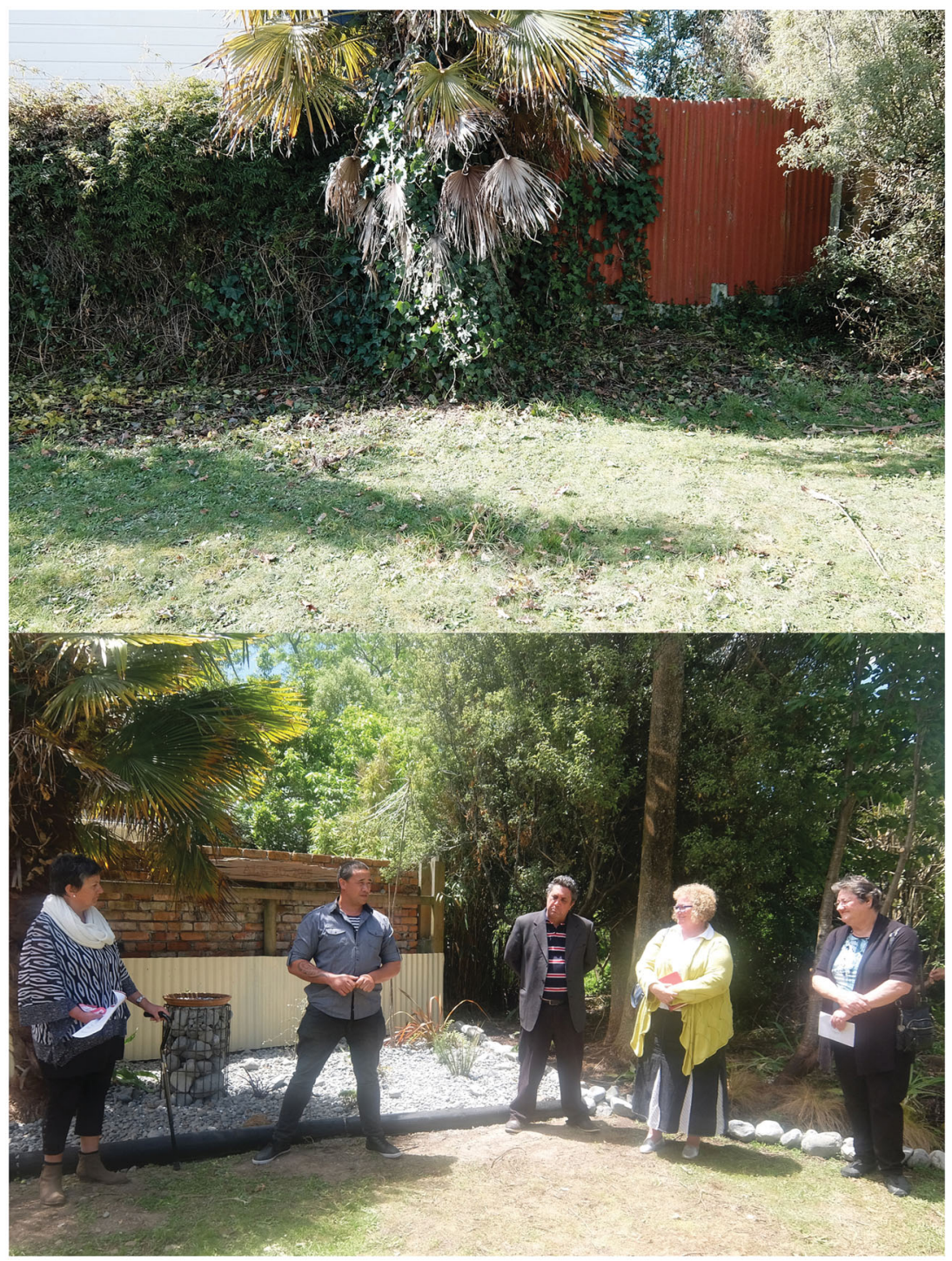

Figure 6

Top: Before work started on the site; Bottom: After work was completed and during the blessing of the garden. Note the carving on the piece of timber on the top of the brick wall reads ALT. ED. 2015. Photographs by Maria Rodgers taken 26 August and 8 December 2015.

For Student $\mathrm{C}$ the most positive impact was getting a younger generation interested and excited about learning new skills. The university students also found that an appreciation of background and learning differences increased, as well as their skills in working with different people. They considered they could apply what they had learned to other projects, university or work. Student D (a tutor) said, "the shift in communication skills has been hugely impactful in my own teaching - particularly with those who aren't as skilled or don't quite have the best use of design language." For Student B, "it was good to take the teaching and supportive experience and apply that to tutoring other [university] students." 
When asked how the project could have been improved, the need

Connecting Māori Youth and Landscape Architecture Students through Participatory Design Maria Rodgers, B. Marques and J. Mclntosh for more time was cited by all. Student C said "more time could have been hugely valuable to develop stronger relationships with the students [rangitahi] and allow them to showcase further their own interests and skills." There were comments regarding the lack of consistency of people power on both sides - rangitahi were frequently absent from class and the university students also had the demands of course and part-time paid work. There was also conflict between achieving what the leaders set out to do and accepting what was possible given the constraints.

Another important finding was that the university student mentors served as a bridge between the rangitahi and project stakeholders, including the AAEP leaders, the church community and marae leaders. The project site was important to the success of the stakeholder engagement. The church grounds served as common ground, a safe place where all could come together with the best interests of the rangitahi at heart. The end result was that the rangitahi created something they could see contributed to society and gave them a sense of achievement and a feeling of value (Figure 7).

The relationship between the rangitahi and university students did not end there. The rangitahi visited the university campus as part of a trip to Wellington and the university students showed them around the facilities and hosted them for kai.

A significant outcome of this project was the experience and recognition of the mutual benefits of co-design, of designing being a collaboration with the user as a partner in the process. There were other positive outcomes despite the scope reduction. This project demonstrated the potential of participatory landscape design projects to enable the reconnection of those disconnected from the land. The rangitahi were introduced to the value of plants, particularly native plants, as well as how to garden and plant. In addition, painting, garden maintenance and working with others in designing and constructing an outdoor space, enabled the practice of kaitiakitanga. The rangitahi experienced the steps in the design process, in particular, the expression and communication of ideas, and how to keep going in face of challenges requiring adjustments to scope and plan. They also experienced positive relationships with people they may not normally come into contact with. The project showed the potential for the participatory process and hands-on implementation of the design to increase engagement with the landscape and to initiate a culture of care.

For the university students the benefits differed. As a voluntary project, separate from university course work, input from committed students from different year levels who would not normally work together was possible. The project helped students see that the value in participatory design is in the participation and the effects this can have on participants, as much as in the resulting implemented design. They also found that developing relationships and learning from each other are 


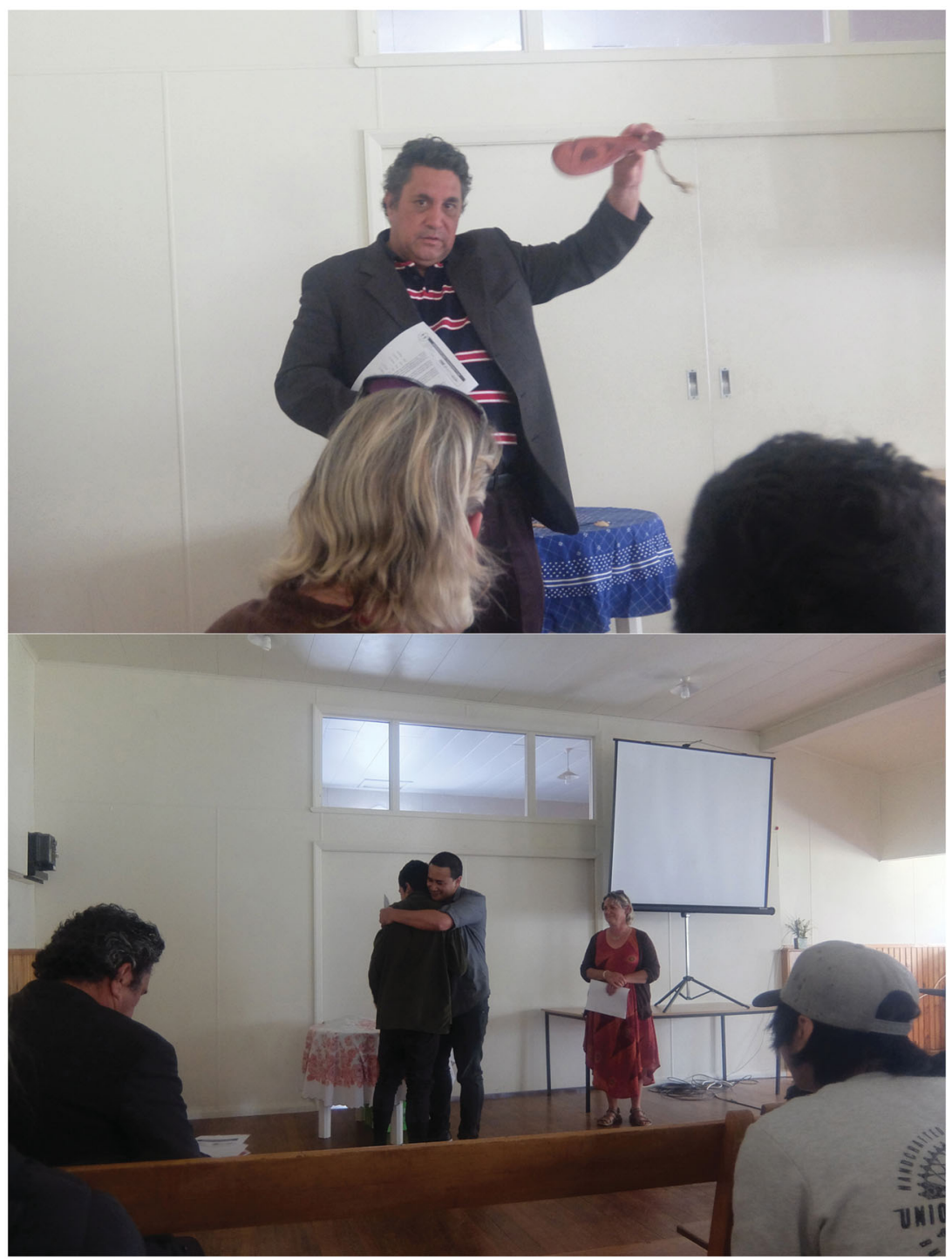

important parts of co-design. Everyone experienced the importance of enduring difficulties to reach resolution, particularly in the face of scope change, and the importance of celebrating the end result.

The study would have been richer if the views of the rangitahi had been recorded, as in the Texas Tech project where the journaled views of the youth expressed pride in seeing their ideas incorporated into the final design. ${ }^{57}$ The planning and structure of the Carterton sessions and decision-making processes could have been improved as communication between the student leaders and the AAEP teacher lacked consistency and decisions were often made in an ad hoc fashion.

\section{Figure 7}

At the awards ceremony: Top: PJ Devonshire, one of the AAEP leaders with a patu, traditional carved club, given to the rangitahi; Bottom: Teaching staff congratulate one of the rangitahi. Photographs by Maria Rodgers taken 8 December 2015. 
The amount of time spent planning such an undertaking cannot

Connecting Māori Youth and Landscape Architecture Students through Participatory Design Maria Rodgers, B. Marques and J. Mclntosh be underestimated. For example, when working with a group, consistency is important and everyone should be equally familiar with the direction and approach taken. In this case a "survey, analysis and design" approach was used, largely because it was familiar to all the university students and time was limited. However, on reflection, it may have been more appropriate and more valuable with regards to the aim of reconnecting the rangitahi to the land, to consider other approaches that focus on phenomenological, experiential investigations of landscape. Additionally, more meaningful design expressive of the personal experience of the rangitahi would have potentially been enabled if responses to the pūrākau heard at noho marae, or stories relating to the site itself, had been woven into the design.

On further reflection, the exploration of a methodology created by Māori for Māori can be useful. Linda Tuhiwai Smith coalesced her list of cultural values for researchers from her book "Decolonizing Methodologies: Research and Indigenous Peoples"58 with Fiona Cram's translations of them to create "A 'community-up' approach to defining researcher conduct." 59 Tuhiwai Smith's cultural value "aroha ki te tangata" became Cram's research guideline "A respect for people - allow people to define their own scope and meet on their own terms." ${ }^{\circ 0}$ Tuhiwai Smith's "manaaki ki te tangata" became the guideline, "Sharing, hosting, being generous. This is a value that underpins a collaborative approach to research, that enables knowledge to flow both ways." ${ }^{61}$ It includes the importance of meeting face-to-face, of looking and listening before speaking, of respecting the dignity of all and of sharing knowledge without flaunting it. These researcher guidelines could be used as guidelines for another kind of collaboration with Māori, for participatory design, and would benefit any participatory design process.

Landscape architecture students, or students from any discipline, who offer to share their skills in participatory design community projects will also have their skills and experience increased in ways they had not foreseen. These can include: an increased ability to communicate with those without "design language"; insight into the lives of those with different backgrounds; the satisfaction of "hands-on" coming together with a variety of people to produce a result; and working on a project they will see implemented.

There are a number of lessons from this project which could be recommendations to those embarking on similar projects. There is a need for designers to meet those they are designing with in their space, in this case a marae, and to spend time with them to gain their trust. The sharing of stories between different groups is an important way to establish mutual respect. In this project there was the sharing of iwi stories and the "story" of landscape architecture. When undertaking participatory design with others flexibility is important, tasks will take longer than envisaged, and goals should be kept achievable or adjusted if not. Continued commitment to a participatory design project in the face 
of obstacles is important. The accessibility of the project site for all

participants is also an important factor in ongoing commitment. The physical distance between the Wellington based university and the Carterton community site was a barrier to more regular attendance by the university student group.

\section{Connecting to the Land through Designing with it}

This project explored how designing with the land can address the problem of reconnection, in particular of Māori youth, to their whenua, their culture and to society, and of how to encourage kaitiakitanga. Indigenous youth were introduced to the importance of landscape to them as tangata whenua and the role that designing landscape can play in bringing people together. University students experienced being mentors and increased their skills in working and communicating with different people, with non-designers. The project validated the potential of collaborative engagement with people who do not often come into contact with one another, in this case landscape architecture university students and Indigenous youth, and of co-designing open space.

The full impacts of these kinds of projects can never be truly known by the researchers. Following the end of the project, the rangitahi dispersed as their program ended and the university students graduated and moved on. The pride and positivity shown in the opening ceremony was deeply memorable. The positive observations by the rangitahi and the learning of the university students were valuable fruit and evidence of a positive outcome. This project sought to design a tangible community improvement, but it became much more about the intangible effects of participatory design on all of those participating, both directly and indirectly. And while university students were mentors to the rangitahi and introduced new skills, it is important to note that the project was instigated by the AAEP leaders and supported by the teachers, iwi from the entire region as well as university staff, a collaborative community effort building community and connections to the whenua.

Maria Rodgers is currently a PhD candidate and teaching fellow in the Landscape Architecture Programme at the Wellington School of Architecture, Victoria University of Wellington. She is particularly interested in participatory design, cultural landscapes, planting design and the use of plants by Indigenous people.

Bruno Marques is a Senior Lecturer in Landscape Architecture and Programme director Landscape Architecture at the Wellington School of Architecture, Victoria University of Wellington. His main research interests relate to the integration of Indigenous methods in participatory design and place-making in landscape rehabilitation and ecosystem services.

Jacqueline Mclntosh is a Senior Lecturer in Architecture at the 
Wellington School of Architecture, Victoria University of Wellington. Her

Connecting Māori Youth and Landscape Architecture Students through Participatory Design Maria Rodgers, B. Marques and J. Mclntosh current research projects revolve around investigating therapeutic and rehabilitative built environments. This multidisciplinary and multiinstitutional bicultural research focusses on the design of the built environment for wellness including social and cultural inclusion.

\section{ORCID}

Maria Rodgers (D) http://orcid.org/0000-0003-2846-1864

B. Marques (iD http://orcid.org/0000-0002-4761-8225

J. Mclntosh (ID http://orcid.org/0000-0001-7896-5089

\section{Notes}

1. Māori, the Indigenous people of Aotearoa New Zealand.

2. Whenua, land, placenta or afterbirth.

3. Bruno Marques, Jacqueline Mclntosh, and William Hatton, "Haumanu Ipukarea, Ki Uta Ki Tai:(Re) Connecting to Landscape and Reviving the Sense of Belonging for Health and Wellbeing," Cities \& Health 2 (2018): 1-9.

4. Russell Bishop et al., "Te Kotahitanga: Addressing Educational Disparities Facing Māori Students in New Zealand," Teaching and Teacher Education 25, no. 5 (2009): 734-42.

5. Pākehā, non-Māori.

6. Mihi, mihimihi, speech of greeting.

7. New Zealand Government, 2014, "Mihimihi," Te Taura Whiri i te Reo Māori - Māori Language Commission, http:// www.tetaurawhiri.govt.nz/maorilanguage/tikanga-maori/mihimihi-en-nz/.

8. Te Reo Māori, the Indigenous language of Aotearoa New Zealand, the language of Māori.

9. Brian Murton, "Embedded in Place: 'Mirror Knowledge' and 'Simultaneous Landscapes' among Māori," in Landscape in Language: Transdisciplinary Perspectives, ed. David M. Mark, et al. (Amsterdam: John Benjamins Publishing, 2011).

10. Pito, umbilical cord.

11. Murton, 'Embedded in Place'.

12. Tangata whenua, people of the land.

13. NZILA, "NZILA Landscape Charter," https://nzila.co.nz/media/uploads/2017_ 01/nzila_draft_charter_final_for_2010_ agm_as_at_24_march_2010.pdf.
14. Linda Clarkson, Vern Morrissette, and Gabriel Regallet, Our Responsibility to the Seventh Generation: Indigenous Peoples and Sustainable Development (Winnipeg: International Institute for Sustainable Development Winnipeg, 1992).

15. M'Lis Bartlett, Participatory Landscape Design with Urban Minority Teens: Building Collective Efficacy for Landscape Stewardship (Ann Arbor: University of Michigan, 2015). R. Mullahey, Y. Susskind, and B. Checkoway, "Youth Participation in Community Planning," in American Planning Association (Chicago, American Planning Association 1999). Wessel Strydom and Karen Puren, "A Participatory Approach to Public Space Design as Informative for Place-Making," Challenges of Modern Technology 4 (2013). Sharon Egretta Sutton and Susan P Kemp, "Children as Partners in Neighborhood Placemaking: Lessons from Intergenerational Design Charrettes," Journal of Environmental Psychology 22, no. 1-2 (2002): 171-189.

16. Ibid.

17. Ibid.

18. Ibid.

19. Mullahey, Susskind, and Checkoway, "Youth Participation in Community Planning."

20. Strydom and Puren, "A Participatory Approach to Public Space Design."

21. Rangitahi, Maori youth.

22. Lynne C. Manzo and Douglas D. Perkins, "Finding Common Ground: The Importance of Place Attachment to 
Community Participation and Planning," Journal of Planning Literature 20, no. 4 (2006): 335-350.

23. Elizabeth B-N Sanders and Pieter Jan Stappers, "Co-Creation and the New Landscapes of Design," Co-Design 4, no. 1 (2008): 5-18.

24. Elizabeth B-N Sanders, "From UserCentered to Participatory Design Approaches," in Design and the Social Sciences (London: CRC Press, 2002).

25. Ibid.

26. Theodore Zamenopoulos and Katerina Alexiou, Co-Design as Collaborative Research, ed. K. Facer and K. Dunleavy, Connected Communities Foundation Series (Bristol: University of Bristol/ AHRC Connected Communities Programme, 2018).

27. Marc Steen, "Co-Design as a Process of Joint Inquiry and Imagination," Design Issues 29, no. 2 (2013): 16-28.

28. Sanders and Stappers, "Co-Creation and the New Landscapes of Design."

29. Sanders, "From User-Centered to Participatory Design Approaches."

30. Jeremy Till. "The Negotiation of Hope," Chap. 2, in Architecture and Participation, ed. Peter Blundell Jones, Doina Petrescu and Jeremy Till (New York: Spon Press, 2005).

31. Bruno Marques, Jacqueline Mclntosh, and Philippe Campays, "Participatory Design for Under-Represented Communities: A Collaborative DesignLed Research Approach for PlaceMaking," in Handbook of Research on Civic Engagement and Social Change in Contemporary Society (Abingdon: IGI Global, 2018).

32. Ibid.

33. Charles H. Klein, Oscar Reyes, Jerome R. Koch, "A Service-Learning Project Involving Multiple Service Projects Including the Mentoring of Younger atRisk Youth," NACTA Journal; Twin Falls 51, no. 4 (2007): 55-61.

34. Ibid.

35. New Zealand Government, "Census Quickstats About a Place: Carterton," Stats NZ (Statistics New Zealand, 2013).

36. Iwi, "extended kinship group, tribe, nation, people, nationality, race - often refers to a large group of people descended from a common ancestor and associated with a distinct territory"

- Moorefield John C, 2019, "Te Aka

Online Māori Dictionary,” https://

maoridictionary.co.nz.

37. Mana whenua, iwi with authority over land or territory.

38. New Zealand Government, 2020, "Alternate Education," Te Kete Ipurangi http://alternativeeducation.tki.org.nz/ Alternative-education.

39. Mātauranga Māori, Māori knowledge or ways of knowing.

40. Kaitiaki, guardian.

41. Kaitiakitanga, guardianship.

42. Merata Kawharu, "Ancestral Landscapes and World Heritage from a Maori Viewpoint," The Journal of the Polynesian Society 118, no. 4 (2009): 317-338.

43. Marques, Mclntosh, and Campays, "Participatory Design for UnderRepresented Communities."

44. NZILA, "NZILA Landscape Charter."

45. Marae, communal and sacred meeting place.

46. Kawa, traditions and protocol.

47. Pūrākau, story, stories.

48. Noho marae, an overnight stay on a marae.

49. Tikanga, how traditions and protocol are carried out, "correct procedure, custom, code ... protocol" - Moorefield, "Te Aka Online Māori Dictionary,"

50. Wharenui, meeting house.

51. Pōwhiri, welcoming ceremony.

52. Kaupapa, "plan, purpose" - Moorefield, "Te Aka Online Māori Dictionary,"

53. Kai, a meal.

54. Karakia, prayer.

55. Patu, a traditional carved club.

56. Mau kaki, carved bone pendant.

57. Klein, Reyes, and Koch, "A ServiceLearning Project Involving Multiple Service Projects."

58. Linda Tuhiwai Smith has been called a Māori post-colonial theorist; however, she has rejected the term in "Decolonizing Methodologies" writing, "Naming the world as 'post-colonial' is, from indigenous perspectives, to name colonialism as finished business." Linda Tuhiwai Smith. Decolonizing Methodologies: Research and Indigenous Peoples. 2nd ed. (London: Zed Books, 2012). 
Connecting Māori Youth and Landscape Architecture Students through Participatory Design Maria Rodgers, B. Marques and J. Mclntosh
59. Linda Tuhiwai Smith, "Researching in the Margins Issues for Māori Researchers a Discussion Paper," AlterNative: An International Journal of Indigenous Peoples 2, no. 1 (September 2006): 4-27.

60. Fiona Cram, "Rangahau Mäori: tōna tika, tōna pono - The Validity and Integrity of

\section{References}

- Bartlett, M'Lis. 2015. Participatory Landscape Design with Urban Minority Teens: Building Collective Efficacy for Landscape Stewardship. Ann Arbor: University of Michigan.

- Bishop, Russell, Mere Berryman, Tom Cavanagh, and Lani Teddy. 2009. "Te Kotahitanga: Addressing Educational Disparities Facing Māori Students in New Zealand." Teaching and Teacher Education 25, no. 5: 734-42. doi:10.1016/j.tate.2009.01.009

- Clarkson, Linda, Vern Morrissette, and Gabriel Regallet. 1992. Our Responsibility to the Seventh Generation: Indigenous Peoples and Sustainable Development. Winnipeg: International Institute for Sustainable Development Winnipeg.

- Cram, F. 2001. Rangahau Mäori: tōna tika, tōna pono-The Validity and Integrity of Mäori Research. In Research Ethics in Aotearoa New Zealand, edited by M. Tolich. Auckland: Pearson Education.

- Kawharu, Merata. 2009. "Ancestral Landscapes and World Heritage from a Maori Viewpoint." The Journal of the Polynesian Society 118, no. 4: 317-38.

- Klein, Charles H., Oscar Reyes, Jerome R. Koch. 2007. "A Service-Learning Project Involving Multiple Service Projects Including the Mentoring of Younger atRisk Youth." NACTA Journal; Twin Falls 51, no. 4: 55-61.

- Manzo, Lynne C., and Douglas D. Perkins. 2006. "Finding Common Ground: The Importance of Place Attachment to Community Participation and Planning." Journal of Planning Literature 20, no. 4: 335-50. doi:10.1177/0885412205286160

- Marques, Bruno, Jacqueline Mclntosh, and Philippe Campays. 2018. "Participatory Design for Under-Represented Communities: A Collaborative Design-Led Research Approach for Place-Making." In
Mäori Research," in Research Ethics in Aotearoa New Zealand, ed. M. Tolich (Auckland: Pearson Education, 2001). 61. Ibid.

Handbook of Research on Civic Engagement and Social Change in Contemporary Society, 1-15. Abingdon: IGI Global.

- Marques, Bruno, Jacqueline Mclntosh, and William Hatton. 2018. "Haumanu Ipukarea, Ki Uta Ki Tai: (Re) Connecting to Landscape and Reviving the Sense of Belonging for Health and Wellbeing." Cities \& Health 2, no. 1: 1-9. doi:10.1080/ 23748834.2018.1514754

- Moorefield John, C. 2019. "Te Aka Online Māori Dictionary.” https://maoridictionary. co.nz.

- Mullahey, R., Y. Susskind, and B. Checkoway. 1999. "Youth Participation in Community Planning." In American Planning Association. Chicago: American Planning Association.

- Murton, Brian. 2011. "Embedded in Place: 'Mirror Knowledge' and 'Simultaneous Landscapes' among Māori." In Landscape in Language: Transdisciplinary Perspectives, edited by David M. Mark, Andrew G. Turk, Niclas Burenhult, and David Stea. Amsterdam: John Benjamins Publishing.

- New Zealand Government. 2020. "Alternate Education." Te Kete Ipurangi. http://alternativeeducation.tki.org.nz/ Alternative-education.

- New Zealand Government. "Census Quickstats About a Place: Carterton.” Statistics New Zealand 2013.

- New Zealand Government. 2014. "Mihimihi." Te Taura Whiri i te Reo Māori Māori Language Commission. http://www. tetaurawhiri.govt.nz/maori-language/ tikanga-maori/mihimihi-en-nz/.

- NZILA. "NZILA Landscape Charter." Wellington. https://nzila.co.nz/media/ uploads/2017_01/nzila_draft_charter_ final_for_2010_agm_as_at_24_march_ 2010.pdf. 
- Sanders, Elizabeth B-N. 2002. "From User-Centered to Participatory Design Approaches." In Design and the Social Sciences, 18-25. London: CRC Press.

- Sanders, Elizabeth B-N, and Pieter Jan Stappers. 2008. "Co-Creation and the New Landscapes of Design." Co-Design 4, no. 1: 5-18.

- Smith, Linda Tuhiwai. 2006. "Researching in the Margins: Issues for Māori Researchers a Discussion Paper." AlterNative: An International Journal of Indigenous Peoples 2, no. 1: 4-27. doi: 10.1177/117718010600200101

- Smith, Linda Tuhiwai. 2012.

Decolonizing Methodologies: Research and Indigenous Peoples. 2nd ed. London: Zed Books.

- Steen, Marc. 2013. "Co-Design as a Process of Joint Inquiry and Imagination." Design Issues 29, no. 2: 16-28. doi:10. 1162/DESI_a_00207

- Strydom, Wessel, and Karen Puren. 2013. "A Participatory Approach to Public
Space Design as Informative for PlaceMaking." Challenges of Modern Technology 4, 33-40.

- Sutton, Sharon Egretta, and Susan P. Kemp. 2002. "Children as Partners in Neighborhood Placemaking: Lessons from Intergenerational Design Charrettes." Journal of Environmental Psychology 22, no. 1-2: 171-89. doi: 10.1006/jevp.2001.0251

- Till, Jeremy. 2005. "The Negotiation of Hope.” Chap. 2 In Architecture and Participation, edited by Peter Blundell Jones, Doina Petrescu, and Jeremy Till. New York: Spon Press.

- Zamenopoulos, Theodore, and Katerina Alexiou. 2018. Co-Design as Collaborative Research. Connected Communities Foundation Series. Edited by K. Facer and K. Dunleavy. Bristol: University of Bristol/ AHRC Connected Communities Programme. 